\title{
PENGARUH LARUTAN COKLAT (Theobroma cacao L) TERHADAP STABILITAS WARNA BASIS GIGI TIRUAN RESIN NILON TERMOPLASTIS
}

\author{
(EFFECT OF BROWN CONDENSATION (Cacao Theobroma L) TOWARD COLOR \\ STABILITY OF DENTURE BASES OF NYLON THERMOPLASTIC RESIN)
}

\author{
Amiyatun Naini \\ Departemen Prostodonsia \\ Fakultas Kedokteran Gigi, Universitas Jember \\ Jl. Kalimantan 37 Jember (0331)333536, 08124918255 , \\ E-mail: amiyatunaini_drg@yahoo.co,id
}

\begin{abstract}
Nylon thermoplastic resin is one of materials for making flexible denture and not use wire as retention, but it has bad physical properties such as absorption of water. In oral cavity, it always contacts with foods and beverages which consumed by people. Chocolate is one of foods which often consumed by people. The aim of this research was to know the effect of brown condensation (Cacao Theobroma L) towards color stability of denture bases of nylon thermoplastic resin. Research used nylon thermoplastic resin (valplast) disk, the size was $10 \mathrm{x} 10 \mathrm{x} 2 \mathrm{~mm}$ that soaked in brown condensation for 7 and 14 days. As control disk was soaked in akuadest. Color stability test used densitometer. The result showed that there was significant difference between control and treatment groups. It is caused by dissolve component/ tannin diffused in capillary stream into nylon thermoplastic resins and caused discolorisation. In conclusion, there is effect of brown condensation (Cacao Theobroma L) towards color stability in denture bases of nylon thermoplastic resin and discolorisation depend on the time of nylon thermoplastic soaking.
\end{abstract}

Key words: brown condensation, color stability, nilon thermoplastic resin

\begin{abstract}
Abstrak
Resin nilon termoplastis merupakan bahan pilihan untuk pembuatan gigi tiruan yang flexible atau lentur dan tidak menggunakan kawat retensi, tetapi mempunyai sifat fisik penyerapan air dalam rongga mulut karena selalu berkontak dengan makanan dan minuman yang dikonsumsi. Salah satu bahan makanan yang sering dikonsumsi oleh masyarakat adalah coklat. Penelitian ini bertujuan untuk mengetahui pengaruh larutan coklat (Theobroma cacao L) terhadap stabilitas warna basis gigi tiruan nilon termoplastis. Sampel penelitian menggunakan nilon termoplastis (valplast) dengan ukuran 10 x 10 × 2mm yang direndam dalam larutan coklat selama 7 dan 14 Sebagai kontrol adalah akuades. Pengujian stabilitas warna menggunakan Densitometer. Hasil penelitian menunjukkan ada perbedaan warna yang bermakna antara kelompok kontrol (akuades) dan kelompok larutan coklat. Hal ini disebabkan komponen terlarut/ tannin mengalami aliran kapiler secara difusi kedalam nilon termoplastis sehingga menyebabkan perubahan warna. Sebagai kesimpulan, terdapat pengaruh larutan coklat (Theobroma cacao L) terhadap stabilitas warna basis gigi tiruan nilon termoplastis tergantung pada waktu perendaman nilon termoplastis.
\end{abstract}

Kata kunci: larutan coklat, stabilits warna, resin nilon termoplastis

\section{PENDAHULUAN}

Saat ini kebutuhan masyarakat terhadap perawatan kesehatan gigi dan mulut semakin meningkat, salah satunya adalah kebutuhan pembuatan gigi tiruan akibat kehilangan gigi yang berfungsi untuk kebutuhan estetis maupun fungsi pengunyahan. Gigi tiruan yang biasa dipakai adalah dari bahan resin akrilik yang warnanya menyerupai gusi dan bahannya kaku. Retensi gigi tiruan diperoleh dengan menggunakan kawat klamer sehingga estetisnya berkurang. ${ }^{1}$

Perkembangan bahan kedokteran gigi sekarang ini disesuaikan dengan keinginan atau bertambahnya 
minat masyarakat untuk memenuhi keindahan/estetis. Banyak pasien lebih memilih gigi tiruan yang tidak menggunakan kawat oleh karena kebutuhan estetis pasien sangat tinggi. Resin nilon termoplastis merupakan bahan pilihan untuk pembuatan gigi tiruan yang fleksibel atau lentur, tidak menggunakan kawat retensi, yang secara formula kimia penyusunnya ada 3 jenis yaitu polyamide (valplast, lucitone, flexite), polycarbonate (reigning, jet carbo resin) dan polyethylene terepthalate (estheshot). Valplast adalah nylon thermoplastic yang lebih tipis dan lebih translusen dari pada gigi palsu biasa. Valplast sangat baik dalam estetika, tidak menggunakan kawat retensi tetapi perlekatan dalam rongga mulut sangat baik sehingga lebih disukai pasien karena nyaman dalam pemakaian dan valplast fleksibel tetapi tetap kuat dan tidak bisa patah. ${ }^{2}$ Basis gigi tiruan nilon termoplastik ini mempunyai sifat fisik yaitu pengerutan, perubahan dimensi dan penyerapan air. Penyerapan air yang tinggi merupakan kekurangan utama nilon. Hal ini disebabkan nilon termoplastik mempunyai serat yang menyerap air. Nilon termoplastik juga memiliki sifat hidroskopi yaitu kemampuan suatu zat untuk menyerap molekul air dari lingkungannya.

Gigi tiruan yang ada dalam rongga mulut akan selalu berkontak dengan makanan dan minuman yang dikonsumsi. Salah satu bahan makanan yang sering dikonsumsi oleh masyarakat adalah coklat yang diolah dari biji kakao. ${ }^{3}$ Menurut data International Cocoa Organization 2003, tingkat konsumsi coklat di Indonesia 12 ribu ton per tahun. ${ }^{4}$ Umumnya halhal yang mendasari konsumen mengonsumsi coklat adalah keinginan konsumen setelah melihat bentuk atau cara penyajian coklat yang menarik. Coklat yang diolah dari biji buah kakao memiliki beberapa kandungan antara lain 2,1\% air; 54,1\% lemak; 2,2\% nitrogen; $0,1 \%$ glukosa; $6,1 \%$ pati; $4,1 \%$ pektin; $2,1 \%$ serat kasar; $1,9 \%$ selulosa; $1,2 \%$ pentose; dan $2,0 \%$ tannin (asam tanat). Kandungan tannin dalam coklat dapat mempengaruhi perubahan warna pada basis gigi tiruan. ${ }^{4}$ Penelitian ini bertujuan untuk mengetahui pengaruh larutan coklat (Theobroma cacao $L$ ) terhadap stabilitas warna basis gigi tiruan nilon termoplastis.

\section{BAHAN DAN METODE}

Jenis penelitian adalah penelitian eksperimental laboratorium dengan rancangan penelitian pre postest control group design, yaitu dilakukan pengukuran (observasi) pada kelompok kontrol dan kelompok perlakuan sebelum dan setelah diberikan suatu perlakuan. Penelitian ini dilakukan di Laboratorium Biologi Farmasi Program Farmasi Universitas
Jember pada bulan Mei-Juni-2011. Sampel penelitian nilon termoplastis (valplast) dengan ukuran 10 $\mathrm{mm} \times 10 \mathrm{~mm} \times 2 \mathrm{~mm} .{ }^{4}$ Kriteria sampel bentuk dan ukuran sampel disesuaikan dengan ukuran cetakan, sampel tidak porus, permukaan halus dan rata, dan tidak berubah bentuk. ${ }^{5}$ Pembagian kelompok sampel penelitian yaitu kelompok kontrol, sebelum dan setelah perendaman 7 hari, sebelum dan setelah perendaman 14 hari. Kelompok perlakuan dalam larutan coklat: sebelum dan setelah perendaman 7 hari, sebelum dan setelah perendaman 14 hari. Jumlah sampel tiap kelompok adalah 6. Penelitian ini dilakukan perendaman selama 7 hari, diasumsikan 7 hari identik dengan pemakaian selama 2 tahun. Misalnya seseorang yang mempunyai kebiasaan mengkonsumsi minuman coklat satu kali sehari. Sekali minum menghabiskan waktu 15 menit. Perendaman selama 7 hari berarti 7 x 24 jam x 60 menit $=10080$ menit: 15 menit/hari $=672$ hari identik dengan pemakaian 2 tahun.

Pembuatan larutan coklat dengan cara bubuk coklat sebanyak 5 gram dilarutkan dalam $625 \mathrm{ml}$ air mendidih. Larutan tersebut diendapkan kemudian diambil sebanyak $500 \mathrm{ml}$, dibiarkan sampai dingin. ${ }^{4}$ Perlakuan sampel nilon termoplastis (valplast) direndam dalam larutan coklat pada suhu ruang, seluruh permukaan valplast harus terendam dalam larutan coklat. Perendaman dilakukan selama 7 dan 14 hari. setiap hari larutan perendam diganti. Sebagai kontrol dilakukan perendaman valplast dalam akuades steril selama 7 dan 14 hari.

Pengujian perubahan warna dilakukan setelah sampel dibersihkan dengan sikat gigi yang halus, dibilas dengan akuades steril dan dikeringkan dimasukkan dan diletakkan pada alat pengukur. Pengukuran dilakukan melalui sinar yang datang dari la UV-Vis, kemudian berkas cahaya yang terbentuk diproyeksikan pada sampel dan dilakukan pengukuran. Intensitas cahaya yang mengenai sampel diukur dengan menggunakan Densitometer merek Camag. ${ }^{6}$

Data yang diperoleh ditabulasi menurut kelompok masing-masing. Kemudian dilakukan uji Kolmogorov-Smirnov dan uji Levene's untuk mengetahui distribusi dan homogenitas data. Selanjutnya data dianalisa dengan One Way Anova, kemudian dilanjutkan dengan uji $L S D$ untuk mengetahui kelompok mana yang berbeda secara bermakna dengan menggunakan tingkat kepercayaan $95 \%(\breve{U}=0,05)$.

\section{HASIL}

Tabel 1 menunjukkan nilai rerata intensitas cahaya antara kelompok kontrol (akuades) dan kelom- 
pok larutan coklat mengalami peningkatan dari sebelum perendaman dan setelah perendaman selama 7 dan 14 hari. Pada kelompok larutan coklat terjadi peningkatan intensitas cahaya lebih besar dibanding kelompok kontrol atau yang direndam dalam akuades. Peningkatan terbesar nilai rerata intensitas cahaya terjadi pada kelompok larutan coklat yang direndam selama 14 hari.

Tabel 1. Nilai rerata dan standar deviasi pengukuran intensitas cahaya nilon termoplastis pada kelompok kontrol (akuades) dan larutan coklat

\begin{tabular}{|c|c|c|c|c|}
\hline \multicolumn{2}{|c|}{ Kelompok } & $\mathrm{n}$ & $\overline{\mathbf{x}}$ & SD \\
\hline \multirow[t]{4}{*}{$\begin{array}{l}\text { Kontrol } \\
\text { (akuades) }\end{array}$} & $\begin{array}{l}\text { Sebelum } \\
\text { perendaman } \\
7 \text { hari }\end{array}$ & 6 & 25966,07 & 1123,24 \\
\hline & $\begin{array}{l}\text { Setelah } \\
\text { perendaman } \\
7 \text { hari }\end{array}$ & 6 & 29551,99 & 1301,58 \\
\hline & $\begin{array}{l}\text { Sebelum } \\
\text { perendaman } \\
14 \text { hari }\end{array}$ & 6 & 24391,80 & 1908,46 \\
\hline & $\begin{array}{l}\text { Setelah } \\
\text { perendaman } \\
14 \text { hari }\end{array}$ & 6 & 30155,77 & 2833,90 \\
\hline \multirow[t]{4}{*}{$\begin{array}{l}\text { Larutan } \\
\text { coklat }\end{array}$} & $\begin{array}{l}\text { Sebelum } \\
\text { perendaman } \\
7 \text { hari }\end{array}$ & 6 & 28777,20 & 4684,52 \\
\hline & $\begin{array}{l}\text { Setelah } \\
\text { perendaman } \\
7 \text { hari }\end{array}$ & 6 & 32411,76 & 3326,85 \\
\hline & $\begin{array}{l}\text { Sebelum } \\
\text { perendaman } \\
14 \text { hari }\end{array}$ & 6 & 25375,81 & 2329,89 \\
\hline & $\begin{array}{l}\text { Setelah } \\
\text { perendaman } \\
14 \text { hari }\end{array}$ & 6 & 34735,01 & 3086,98 \\
\hline
\end{tabular}

Hasil nilai rerata pengukuran intensitas cahaya pada kelompok kontrol dan larutan coklat dapat dilihat pada Grafik 1.

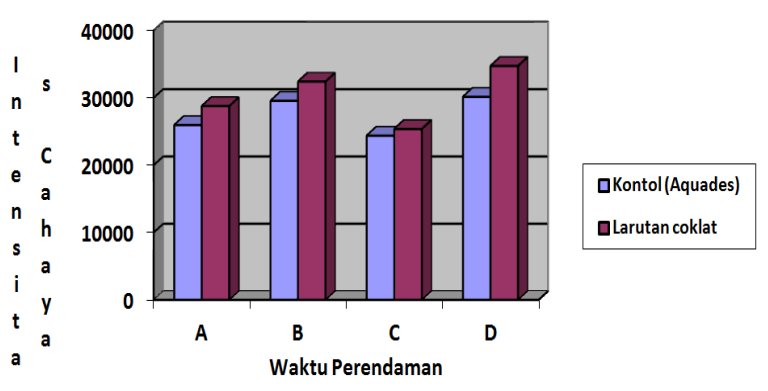

Grafik 1. Nilai rerata pengukuran intensitas cahaya pada kelompok kontrol dan larutan coklat A: Sebelum perendaman selama 7 hari, B: Setelah perendaman selama 7 hari, C: Sebelum perendaman selama 14 hari, D: Setelah perendaman selama 14 hari
Selanjutnya dilakukan uji normalitas Kolmogorof Smirnov untuk mengetahui normalitas data, diperoleh nilai 0,662 . Hal ini menunjukkan bahwa tingkat kemaknaan > 0,05 berarti data berdistribusi normal. Selanjutnya dilakukan uji homogenitas, hasilnya 0,331 , hal ini menunjukkan tingkat kemaknaan $>0,05$ berarti data homogen. Data yang diperoleh selanjutnya diuji menggunakan anova satu arah untuk mengetahui pengaruh perendaman basis gigi tiruan dari nilon termoplastis dalam larutan coklat terhadap nilai intensitas cahaya diperoleh nilai 0,016 yang berarti nilai signifikansi $(<0,05)$. Hal ini menunjukkan terdapat perbedaan yang bermakna antara kelompok kontrol (akuades) dan kelompok larutan coklat. Untuk mengetahui besar beda rerata nilai intensitas cahaya antara kelompok kontrol (akuades) dan kelompok larutan coklat dilanjutkan dengan uji LSD.

Tabel 2. Hasil uji LSD nilai intensitas cahaya nilon termoplastis pada kelompok kontrol (akuades) dan larutan coklat selama 7 dan 14 hari

\begin{tabular}{lcccc}
\hline Kelompok & $\begin{array}{c}\text { Kontrol } \\
\text { (akua) } \\
\text { selama } \\
7 \text { hari }\end{array}$ & $\begin{array}{c}\text { Larutan } \\
\text { coklat } \\
\text { selama } \\
7 \text { hari }\end{array}$ & $\begin{array}{c}\text { Kontrol } \\
\text { (akua) } \\
\text { selama } \\
14 \text { hari }\end{array}$ & $\begin{array}{c}\text { Larutan } \\
\text { coklat } \\
\text { selama } \\
14 \text { hari }\end{array}$ \\
\hline $\begin{array}{l}\text { Kontrol } \\
\text { (akua) selama }\end{array}$ & - & 0,087 & 0,708 & 0,004 \\
7 hari & & & & $(\mathrm{B})$ \\
$\begin{array}{l}\text { Larutan } \\
\text { coklat selama }\end{array}$ & 0,087 & - & 0,171 & 0,159 \\
7 hari & & & & \\
$\begin{array}{l}\text { Kontrol } \\
\text { (akua) selama }\end{array}$ & 0,708 & 0,171 & - & 0,009 \\
14 hari & & & & $(\mathrm{B})$ \\
$\begin{array}{l}\text { Larutan } \\
\text { coklat selama }\end{array}$ & 0,004 & 0,159 & 0,009 & - \\
14 hari & (B) & & (B) & \\
\hline
\end{tabular}

Tabel 2 menunjukkan nilon termoplastis yang direndam dalam akuades sebagai kelompok kontrol selama 7 hari dibandingkan dengan nilon termoplastis yang direndam dalam larutan coklat selama 7 hari tidak ada perbedaan bermakna. Yang berbeda bermakna adalah antara nilon termoplastis yang direndam dalam akuades selama 7 hari dengan nilon termoplastis yang direndam dalam larutan coklat selama 14 hari dan nilon termoplastis yang direndam dalam akuades selama 14 hari dengan nilon termoplastis yang direndam dalam larutan coklat selama 14 hari

\section{PEMBAHASAN}

Dalam praktek dokter gigi, banyak pasien yang lebih memilih gigi tiruan yang tidak menggunakan 
kawat oleh karena kebutuhan estetik pasien sangat tinggi. Resin nilon termoplastis merupakan bahan pilihan untuk pembuatan gigi tiruan yang fleksibel atau lentur tidak mudah patah, tidak menggunakan kawat retensi, lebih tipis dan lebih translusen daripada gigi tiruan yang lain. ${ }^{2}$ Tetapi basis gigi tiruan nilon termoplastik ini juga mempunyai sifat fisik yang kurang menguntungkan yaitu pengerutan, perubahan dimensi dan penyerapan air. Penyerapan air yang tinggi merupakan kekurangan utama nilon. Hal ini disebabkan nilon termoplastik mempunyai serat yang menyerap air. Nilon termoplastik juga memiliki sifat hidroskopi yaitu kemampuan suatu zat untuk menyerap molekul air dari lingkungannya.

Penelitian ini melakukan perendaman basis gigi tiruan nilon termoplastis dalam akuades steril yaitu sebagai kelompok kontrol dan dalam larutan coklat sebagai kelompok perlakuan selama 7 dan 14 hari. Pada Tabel 1 diperoleh hasil data pengukuran intensitas cahaya setelah perendaman lebih besar dari sebelum perendaman baik yang direndam dalam akuades maupun larutan coklat, hal ini menunjukkan bahwa cairan akan terserap oleh nilon termoplastis sehingga berpengaruh pada nilai intensitas cahaya. Sesuai pernyataan Phillip, pada nilon termoplastis yang berkontak dengan cairan umumnya akan terjadi penyerapan cairan atau terjadi difusi (berpindahnya suatu substansi melalui rongga. ${ }^{7}$ Menurut Takabayashi fenomena penyerapan air yang terjadi pada resin termoplastis oleh karena tingginya sifat hidrofili dari bentukan amida yang menyusun rantai utama resin poliamide, sehingga tingginya penyerapan air searah dengan banyaknya konsentrasi rantai amide pada resin. ${ }^{8}$

Salah satu cara untuk mengamati perubahan warna yang terjadi adalah dengan menggunakan densitometer yang dapat mengukur besarnya intensitas cahaya yang diserap oleh suatu benda. Nilai absorbansi unit pada Densitometer akan menurun bila cahaya yang dipantulkan lebih banyak dari cahaya yang diteruskan, hal ini berarti bila warna tersebut menjadi lebih muda atau mengarah kewarna putih berarti lebih banyak spektrum yang dipantulkan daripada yang diteruskan, sehingga nilai absorbs unit menjadi turun. ${ }^{9}$

Dalam larutan coklat selama 7 dan 14 hari terjadi peningkatan nilai intensitas cahaya pada nilon termoplastis. Sampel yang direndam dalam larutan coklat selama 7 hari mempunyai rerata nilai intensitas cahaya 32411,76. Sampel yang direndam dalam larutan coklat selama 14 hari mempunyai rerata nilai intensitas cahaya 34735,01. Hasil pengukuran intensitas cahaya pada sampel yang direndam dalam larutan coklat selama 7 hari menunjukkan bahwa dalam waktu 7 hari sudah terjadi peningkatan nilai intensitas cahaya pada nilon termoplastis dan dapat disimpulkan bahwa perendaman nilon termoplastis ke dalam larutan coklat selama 7 hari sudah mampu menimbulkan perubahan warna. Hal ini disebabkan komponen terlarut/ tannin mengalami aliran kapiler secara difusi kedalam nilon termoplastis. Hal ini didukung oleh Takabayashi yang menyatakan bahwa terdapat perubahan warna pada resin termoplastis setelah berkontak dengan beberapa minuman. Perubahan warna terjadi oleh karena penetrasi fisik dari pigmen antara molekul latik atau penyerapan pigmen pada permukaan resin nilon termoplastis. ${ }^{8}$

Hasil uji Anova satu arah terdapat perbedaan antara kelompok kontrol (akuades) dan perlakuan (larutan coklat) terhadap nilai intentensitas cahaya nilon termoplastis dengan nilai signifikansi sebesar $0,016$ ( $p<0,05)$. Terdapat perbedaan bermakna nilai intensitas cahaya antara kelompok kontrol (akuades) dan perlakuan (larutan coklat) diduga adanya komponen tannin dari larutan coklat dengan ikatan rangkap dua yang terkonjugasi pada polifenol berfungsi sebagai kromofor (pengemban warna) dan adanya gugus $(\mathrm{OH})$ pada tannin berfungsi sebagai auksokrom (pengikat warna). Adanya kromofor dan auksokrom pada tannin dapat menyebabkan warna coklat. ${ }^{4}$ Didukung pula oleh Craig,dkk, bahwa zat warna alami terserap oleh resin akan menyebabkan perubahan warna. ${ }^{10}$ sehingga hasil uji berbeda secara bermakna.

Pada Tabel 2 hasil uji LSD diperoleh nilai yang berbeda bermakna adalah antara nilon termoplastis yang direndam dalam akuades selama 7 hari dengan nilon termoplastis yang direndam dalam larutan coklat selama 14 hari, nilon termoplastis yang direndam dalam akuades selama 14 hari dengan nilon termoplastis yang direndam dalam larutan coklat selama 14 hari. Hal ini menunjukkan bahwa semakin lama waktu perendaman nilon termoplastis dalam larutan coklat maka nilai intensitas cahaya semakin tinggi sehingga terjadi perbedaan secara bermakna dibanding dengan kelompok kontrol (akuades) yang ditunjukkan dengan semakin besar juga perubahan warna yang terjadi. Diduga terjadi akumulasi pigmen warna tannin pada permukaan nilon termoplastis dan penyerapan warna juga lebih banyak daripada yang dipantulkan sehingga nilon termoplastis menjadi lebih gelap

Pada penelitian ini menggunakan waktu perendaman selama 7 dan 14 hari, semakin lama waktu perendaman nilon termoplastis dalam larutan coklat, semakin besar juga perubahan warna yang terjadi. Sesuai dengan asumsi bahwa 7 hari perlakuan sampel identik dengan pemakaian basis nilon termoplastis selama 2 tahun, basis nilon termoplastis ter- 
sebut sudah mengalami perubahan warna menjadi lebih gelap. Sesuai pernyataan Phillip bahwa penyerapan zat warna cairan dapat terjadi secara perlahan-lahan dalam jangka waktu tertentu dengan mekanisme difusi air. ${ }^{7}$

Perubahan warna pada basis gigi tiruan nilon termoplastis tidak selalu permanen karena dapat berkurang setelah dilakukan perbersihan dengan menggunakan sikat gigi halus. Asumsi ini sesuai dengan pernyataan Rohati Ningrum bahwa kemungkinan cairan atau partikel yang terserap akan hilang pada saat penyikatan atau pemulasan kembali. ${ }^{11}$ Sebagai kesimpulan, terdapat pengaruh larutan coklat (Theobroma cacao $L$ ) terhadap satbilitas warna basis gigi tiruan nilon termoplastis dan semakin lama waktu perendaman nilon termoplastis semakin besar perubahan warnanya.

\section{Daftar Pustaka}

1. Anusavice KJ. Philips: Buku Ajar Ilmu Bahan Kedokteran Gigi.Edisi 10. Alih Bahasa. Johan Arief Budiman. Susi Purwoko. Jakarta. EGC, 2004: 22.

2. Ditolla M. Valplast: flexible, aesthetic partial dentures. Chairside Perspective. 2005; 5(1).

3. Triatmojo. Coklat. http://triatmojo. wordpress.com/ 2006/09/06/coklat. (6 September 2006).

4. Wijaya. Pengaruh larutan coklat (Theobroma cacao
L) terhadap perubahan warna pada anasir gigi tiruan resin akrilik. Skripsi. Jember; Fakultas Kedokteran Gigi Universitas Jember. 2008. 10-5.

5. Meizarini. Pengaruh perendaman basis gigi tiruan resin akrilik tipe cross-linked dalm glutaraldehyde terhadap pertumbuhan C.albicans. Majalah Kedokteran Gigi FKG Airlangga. 2002. 35. 164

6. Laode. Scanner 3 for Densitometric Evaluation of Thin Laper Chromatograms.http://www. Pascounhas .net/jurnal-pdf (18 Mei 2007).

7. Phillips RW. Buku Ajar Ilmu Kedokteran Gigi, Edisi 10. Jakarta. EGC. 2003. 223-4

8. Takabayashi. Characteristics of denture thermoplastic resins for non-metal clasp dentures Dental Materials Journal Tsurumi University School of Dental Medicine, 2-1-3 Tsurumi, Tsurumi-ku, Yokohama, Kanagawa 230-8501, Japan; 2010. 29 (4): 353-61

9. Vergadian. Kit eksperimentasi pengukuran berbasis intensitas cahaya. http://www.Stei.itb.ac.id/d4-otomasi/images/stories/TA06-07/vergadian (1 Nopember 2008).

10. Ođ̊Brien J, William. Dental materials and their selections. 3rd ed. Canada: Quintessance Publishing Co, Inc. 2002: 40.

11. Rohatiningrum. Pengaruh larutan coklat (Theobroma cacao L) terhadap perubahan warna resin akrilik. Skripsi Jember; Fakultas Kedokteran Gigi Universitas Jember. 2003: 35. 